\title{
Effect of the Bonito Insulin on the Insulin Release from Monolayer Culture of Rat Pancreas
}

\author{
Hisako OHGAWARA ${ }^{1}$, Yoshimasa TASAKA ${ }^{1}$ \\ AND YASUNORI KANAZAWA ${ }^{2}$ \\ ${ }^{1}$ The Diabetic Center, Tokyo Women's Medical College, \\ Shinjuku-ku, Tokyo 162, Japan and ${ }^{2}$ The Third \\ Department of Internal Medicine, Faculty of Medicine, \\ University of Tokyo, Bunkyo-ku, Tokyo 113, Japan
}

\begin{abstract}
Synopsis
The effect of bonito insulin on insulin release was examined in the monolayer culture of rat pancreatic $\beta$-cells. The $\beta$-cells were preincubated for 5 to $20 \mathrm{hr}$ with or without a small dose $(100 \mu \mathrm{U} / \mathrm{ml})$ of bonito insulin in the medium containing $100 \mathrm{mg} \%$ glucose. And then, they were incubated in $300 \mathrm{mg} \%$ glucose alone or together with bonito insulin for $5 \mathrm{hr}$. There was no significant difference between the IRI release from these $\beta$-cells with or without bonito insulin. The concentration of bonito insulin was augmented from $100 \mu \mathrm{U} / \mathrm{m} l$ to $500,1,000$ and $2,000 \mu \mathrm{U} / \mathrm{ml}$. A significant inhibitory effect on the glucose-induced insulin release was observed only after the preincubation for $20 \mathrm{hr}$ with $2,000 \mu \mathrm{U} / \mathrm{ml}$ of bonito insulin.
\end{abstract}

Previously, we found that the infusion of a small dose of bonito insulin, which was ineffective on the blood sugar levels, resulted in an inhibition of glucose-induced insulin secretion in man and dogs (Ohgawara et al., 1973 and 1974), but more than 20 $\mathrm{hr}$ of insulin infusion was necessary to inhibit the glucose induced insulin secretion. It still remains to be established whether a direct or indirect feedback mechanism is responsible for this inhibition. Evidence for a direct effect of insulin on insulin release was reported in several studies (Chu and Gooder, 1968; Hahn and Michael, 1971; Iversen and Miles, 1971; Sodoyez et al., 1969; Ammon et al., 1973). On the other hand, some investigators found no inhibition of insulin secretion by insulin (Grodsky et al., 1968; Curry et al., 1968; Malaisse et al., 1967; Sando et al., 1970).

The present studies were undertaken, therefore, to determine the effect of exo-

Received December 21, 1977. genous insulin on insulin release from the monolayer culture of rat pancreatic cells.

\section{Materials and Methods}

The procedures used to prepare the monolayer cultured cell of pancreas were based on the method described by Lambert et al. (Lambert et al., 1974). Pancreases were removed from newborn rats aged 3 to 5 days and cut into small pieces. Then these fragments were dissociated in a enzyme solution containing $0.25 \%$ trypsin $(1: 250$, Gifco) and $0.01 \%$ collagenase (Type DLS, Worthington Biochemical Corp.) at $37^{\circ} \mathrm{C}$ with stirring. This procedure was repeated until complete digestion of the tissue. The dissociated cells were collected by centrifugation and the pellet of cells was suspended in "culture medium" (TC 199 Earle's solution, Flow Lab. Inc. U.S.A., supplemented with fetal calf serum, Flow Lab. Inc. and $300 \mathrm{mg} / 100 \mathrm{ml}$ of glucose). Aliquots were distributed in plastic culture dishes (Petri type, Falcon Plastic), and incubated at $37^{\circ} \mathrm{C}$ in a humidified atmosphere of $95 \%$ air and $5 \% \mathrm{CO}_{2}$. The pancreatic cells were grown for 4 days in the culture medium indicated above. At the end of this 4-day period, they were incubated for $2 \mathrm{hr}$ with the control medium that was consisted of TC $199,100 \mathrm{mg} / 100 \mathrm{ml}$ glucose, and $10 \%$ fetal calf serum (pre-preincubation). 
In order to determine the effect of bonito insulin on insulin release from cultured $\beta$-cells, seven types of experiment were carried out (Fig. 1). The $\beta$-cells were incubated for $5 \mathrm{hr}$ after $2 \mathrm{hr}$ pre-preincubation with "control medium" with or without $100 \mu \mathrm{U} / \mathrm{m} l$ of bonito insulin (Group I). The same type of experiment was carried out with "culture medium" (Group II). From Group III to VI, the cultured cells were preincubated in control medium for 5 , $10,15,20 \mathrm{hr}$ with or without $100 \mu \mathrm{U} / \mathrm{ml}$ of bonito insulin after $2 \mathrm{hr}$ pre-preincubation. The cells were washed twice with $1 \mathrm{~m} l$ of corresponding medium, then incubated for $5 \mathrm{hr}$ with "culture medium", with or without $100 \mu \mathrm{U} / \mathrm{ml}$ of bonito insulin. In the group, the cells were preincubated in the control medium for $20 \mathrm{hr}$ with or without $500,1,000$ or $2,000 \mu \mathrm{U} / \mathrm{m} l$ of bonito insulin. Incubation was carried out in the culture medium for $5 \mathrm{hr}$ containing the same consentrations of bonito insulin which were present in preincubation. After the incubation, each petri dish was extracted with acid ethanol (Scott and Fihers, 1938) to determine the insulin content. Since there were some variation of the number of $\beta$-cells from petri to petri, insulin content of each dish was used as an index of the amount of $\beta$-cells in that dish. The IRI release could be expressed as $\mu \mathrm{U}$ released in the incubation medium per $\mathrm{mU}$ content in the extract. Each aliquot of incubation medium was stored at $-20^{\circ} \mathrm{C}$ until assay and was analyzed for insulin content by radioimmunoassay by the method of Morgan and Lazarow (Morgan and Lazarow, 1963) using purified rat insulin as a standard. IRI in the acid ethanol was directly measured after appropriate dilution with buffer used for radioimmunoassay.
The system of radioimmunoassay used here was the same as that described in the previous report (Ohgawara, 1974). The cross-reactivity of bonito insulin with rat insulin in our assay system is less than $5 \%$, therefore that is almost negligible.

\section{Results}

Morphology of the cultured $\beta$-cells did not alter their appearance throughout the experiment. At the end of the experiment, the contents of some of these petri dishes were fixed by Bouin's solution and stained with aldehyde-fuchsin. In most of the clusters, aldehyde-fuchsin-positive cells were found presumably $\beta$-cells. Table 1 summarizes the results of experiments studying the effect of glucose alone or together with bonito insulin on IRI release from monolayer cultured pancreatic cells.

The IRI concentration of the media after incubation ranged from 1000 to $5000 \mu \mathrm{U} / \mathrm{m} l$. The IRI release with $100 \mathrm{mg} / 100 \mathrm{ml}$ glucose was $11.9 \pm 0.7 \mu \mathrm{U} / \mathrm{mU}$ per dish. Increasing the glucose concentration to $300 \mathrm{mg} /$ $100 \mathrm{ml}$, IRI release was markedly stimulated during the 5 -hr incubation period $33.5 \pm$ $4.6 \mu \mathrm{U} / \mathrm{mU}$ per dish $)(\mathrm{P}<0.001)$.

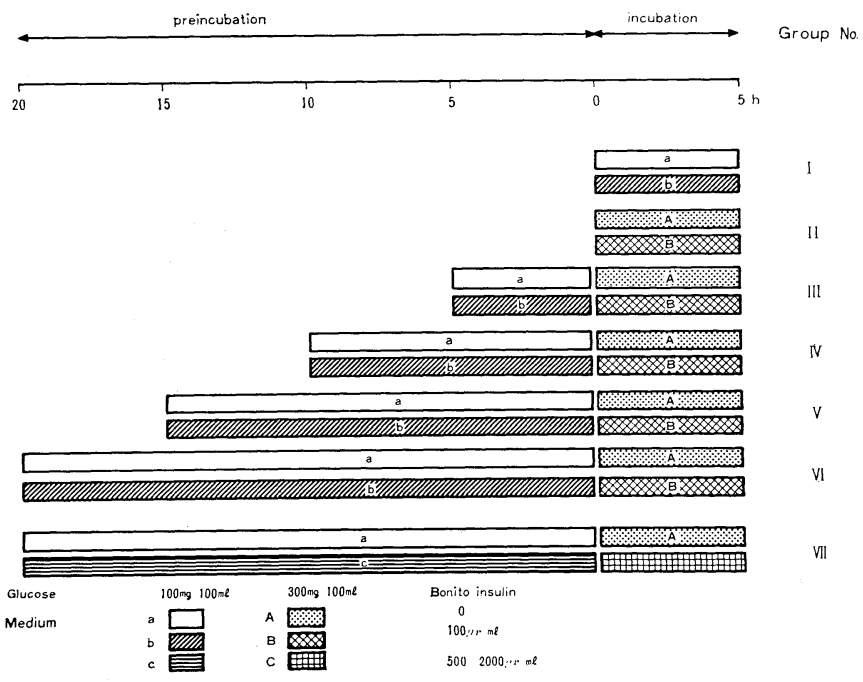

Fig. 1. Schematic outline of experimental protocol. 
The addition of $100 \mu \mathrm{U} / \mathrm{m} l$ of bonito insulin to the preincubation and incubation medium did not inhibit IRI output under the condition of $100 \mathrm{mg} / 100 \mathrm{~m} l$ glucose and/ or $300 \mathrm{mg} / 100 \mathrm{ml}$ glucose (Table 1).

The duration of preincubation was prolonged from $5 \mathrm{hr}$ to $20 \mathrm{hr}$, and no inhibitory effect on insulin release appeared by the addition of $100 \mu \mathrm{U} / \mathrm{m} l$ bonito insulin (Table 1). Finally, the concentrations of bonito insulin were elevated to $500,1,000$ and $2,000 \mu \mathrm{U} / \mathrm{m} l$ (Group VII), and the significant inhibition of insulin release appeared only in the presence of $2,000 \mu \mathrm{U} / \mathrm{m} l$ of bonito insulin $(\mathrm{P}<0.01)$.

\section{Discussion}

Previously, we found that the systemic infusion of a small dose of exogenous bonito insulin resulted in and inhibition of glucose-induced insulin secretion in man and in dogs. However, prolonged insulin infusion was necessary to obtain a signifi- cant inhibition of glucose-induced insulin release (Ohgawara et al., 1973 and 1974). The inhibition of insulin release was also observed in the in vitro incubation with cultured pancreatic $\beta$-cells only after preincubation for $20 \mathrm{hr}$ with bonito insulin of $2,000 \mu \mathrm{U} / \mathrm{m} l$. The prolonged incubation with bonito insulin had no effect on the extractable insulin in cultured cells.

This result may support the possibility of the existence of a direct feedback mechanism of insulin on insulin release. From this viewpoint, our result is in keeping with some of the reports (Hahn, 1971; Iversen, 1971; Ammon et al., 1973; Sodoyez et al., 1969). While Grodsky (1968) reported that the inhibitory effect of insulin on insulin secretion could not be detected in the isolated rat pancreas perfused with rat insulin. He used rather small amount of rat insulin $(100 \mu \mathrm{U} / \mathrm{m} l)$ and perfused for a short period $(30 \mathrm{~min})$; therefore the inhibitory effect of rat insulin might not have appeared in his experiment. The necessity of prolonged exposure of the $\beta$-cells to fairly

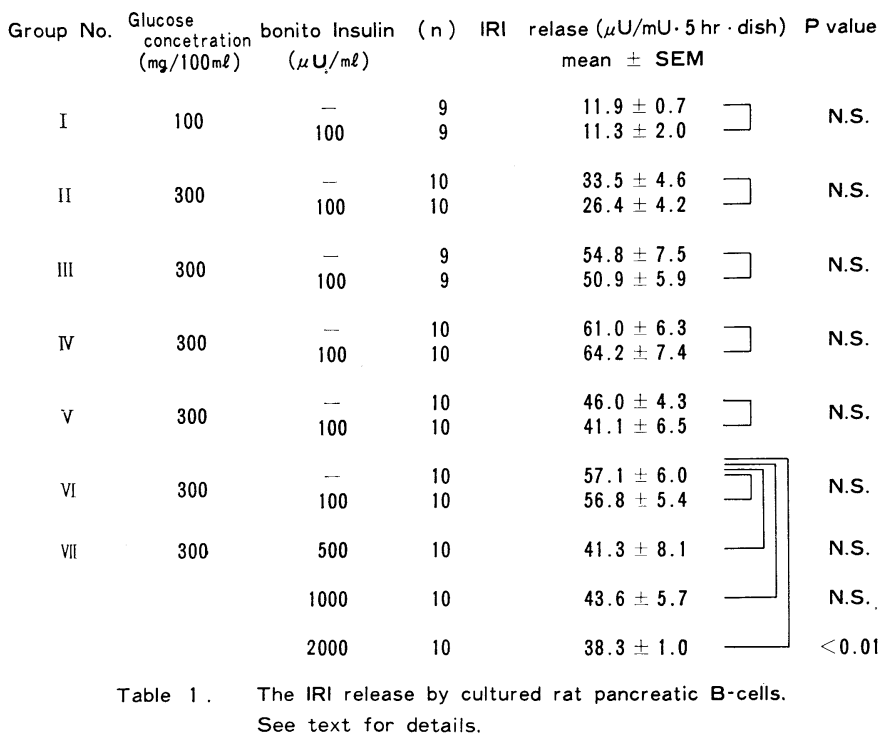

Table 1. The IRI release by cultured rat pancreatic $\beta$-cells. Details are described in the text. 
high dose of insulin might suggest that some metabolic changes in $\beta$-cell were important for the inhibition of insulin release.

In contrast to our previous experiment in vivo, the experiment presented here indicates that the relatively high concentration of bonito insulin was necessary to inhibit the glucose-stimulated insulin release. This discrepancy between the in vivo and in vitro experiment could be explained as follows; firstly, the non-significant blood sugar change by bonito insulin administration could have some effect on insulin release in vivo; secondly the extracellular environment of the cultured cell might be quite different from that of cells in the tissue, and such a micro-environment of $\beta$-cells especially in insulin concentration might have some effect on the sensitivity of $\beta$-cells to insulin. There is another possibility which cannot be ruled out that a high concentration of bonito insulin could have some protective effect and decrease the leakage of insulin from islet cells during the prolonged incubation.

\section{References}

Ammon, H. P. T., J. P. Assal and J. Steinke (1973). The 33rd Annual Meeting, Los Angeles, Ca., Vol. 22 Supplement 297.

Chu, P. C. and C. J. Goodner (1968). Endocrinology $82,296$.

Curry, D. L., L. L. Bennett and G. M. Grodsky (1968). Endocrinology 83, 572.

Grodsky, G. M., B. A. R. Fanska and F. G. Schmid (1973). Diabetes 22, 256.

Hahn, H. J. and R. Michael (1971). J. Clin. Invest 50, 98.

Iversen, J. and D. W. Miles (1971). Diabetes 20, 1. Lambert, A. E., B. Blondel, Y. Kanazawa, L. Orci and A. E. Renold (1972). Endocrinology 90, 239.

Malaisse, W. J., F. L. Malaisse, P. E. Lacy and P. H. Wright (1967). Proc. Soc. Exp. Biol. Med. 124, 497.

Ohgawara H., K. Suzuki and K. Kosaka (1973). Endocrinol. Japon. 20, 307.

Ohgawara H., Y. Tasaka, K. Kosaka and K. Shizume (1974). ibid. 21, 147.

Sando, H., Y. Kanazawa and T. Kuzuya (1970). Am. J. Physiol. 218, 1,357.

Scott, D. A. and A. M. Fisher (1938). J. Clin. Invest. 17, 725 .

Sodoyez F. G., J. C. Sodoyez and P. P. Foa (1969). Proc. Soc. Exp. Biol. Med. 130, 568. 